\author{
Галина Хомич, \\ кандидат психологічних наук, \\ професор, завідувач кафедри \\ психології ДВНЗ «Переяслав- \\ Хмельницький державний \\ педагогічний університет \\ імені Григорія Сковороди» \\ E-mail: kaf_psih_phdpu@ukr.net \\ ORCID 0000-0001-8748-8165 \\ Юлія Шамардак, \\ викладач кафедри психологіi \\ ДВНЗ «Переяслав-Хмельнищький \\ державний педагогічний \\ університет імені Григорія \\ Сковороди» \\ Halyna Khomych, \\ PhD (Psychology), \\ Professor, Head of the Department \\ of Psychology \\ SHEI «Pereiaslav-Khmelnytskyi \\ Hryhorii Skovoroda State Pedagogical \\ University» \\ E-mail: kaf_psih_phdpu@ukr.net \\ ORCID 0000-0002-0768-6792 \\ Yuliia Shamardak, \\ lecturer of the Department \\ of Psychology \\ SHEI «Pereiaslav-Khmelnytskyi \\ Hryhorii Skovoroda State Pedagogical
}

\title{
АТРАКЦІЯ ЯК СКЛАДОВА МІЖОСОБИСТІСНОЇ ПЕРЦЕПЦІї У ПРОФЕСІЙНІЙ ДІЯЛЬНОСТІ ПСИХОЛОГА
}

У статті представлено теоретичний огляд наукових підходів до вивчення психологічних факторів міжособистісної атракції. Міжособистісну атракцію означено як структурну складову соціальної периепиіі, щзо характеризує односторонню чи взаємну привабливість учасників комунікативного прочесу, яка зумовлена системою внутрішніх $i$ зовнішніх факторів та базується на механізмах психологічного впливу. Розкрито дефініцію атракиії у контексті зарубіжних та вітчизняних концепцій соціальної психології, де досліджуване поняття презентовано як гаму почуттів у діапазоні від неусвідомленого потягу до симпатії, любові, щзо проявляється у вигляді особливої соиіальної настанови щзодо суб 'єкта взаємодії. 3'ясовано, щцо актуальними аспектами міжособистісної атракцї психолога та клієнта є позитивне емоційне ставлення, схожість поглядів на сучасне суспільство, пізнавальні інтереси, а також готовність до особистісних змін, індивідуально-типологічні характеристики учасників комунікації. Емпірично виокремлено основні риси, якими має володіти сучасний атрактивний психолог з позицій студентів: чуйність, емпатійність, тактовність, стриманість, врівноваженість, порядність, чесність, етичність, уважність $i$ спостережливість; з позииї дипломованих фахівиів: освіченість, ерудиція, привітність, доброзичливість, компетентність, комунікабельність, асертивність, толерантність. Зроблено висновки, щуо носіями певної інформації можуть виступати зовнішній вигляд і поведінка людини, які формують перше враження та можуть відштовхнути або привабити співрозмовника; однак тривалі стосунки формуються на базі певних рис особистостей, їхніх смислових стратегій та емоиійного ставлення, цінностей та психологічних настанов.

Ключові слова: психолог, професійна взаємодія, міжособистісна атракиія, психологічна привабливість, сочіальна периепція.

The article deals with the theoretical review of scientific approaches to psychological factors of the interpersonal attraction. In particular, the interpersonal attraction is intended to describe as a structural component of social perception, which characterizes the one-sided or interattraction of participants in the communicative process. It is due to the system of internal and external factors and 


\section{Psychology}

based on the psychological influence mechanisms. The definition of attraction is revealed within the foreign and domestic conceptual framework of social psychology. The studying concept is presented as a gamut of feelings over the range unconscious attraction to sympathy, love, and manifested as a special social attitude towards the subject of interaction. Scientists differentiate the cognitive component of the emotional relationship to the interaction partner, the motivational component, the value system, patterns of the social perception and such like among structural components of the interpersonal attraction. It has been found that the actual aspects of the psychologists to clients' interpersonal attraction are the positive emotional attitude, similarity of views on the modern society, cognitive interests, and also readiness for personal changes, individual typological characteristics of communication participants. Main features of the modern attractive psychologist from the standpoint of students and graduates are empirically highlighted. Considering the average indicator, the attractive psychologist must be professionally competent and erudite. Also he should possess such personal qualities as affability, amiability, emotional generosity, empathy, tacticity, unsociable demeanour, tranquility, respectability, honesty, ethicality, communicability, sociability, sense of humor. These are echoed with the foreign experts' opinions from different fields of applied psychology. Practical experienced psychologists attach great importance to such characteristics as education, erudition, friendliness, goodwill, competence, communication skills, assertiveness, tolerance. Rank values in the samples of graduate psychologists and experienced specialists are most different in such features as image, style, culture of speech, selfdiscipline, punctuality, tolerance, patience, purposefulness, responsiveness, empathic. The bearers of certain information may be the person's appearance and behavior, which form the first impression and may repel or attract the interlocutor. However, the long-term relationships are formed on the basis of certain personality traits, their semantic strategies and emotional attitudes, values and psychological attitudes.

Keywords: psychologist, professional interaction, interpersonal attraction, psychological attraction, social perception

Постановка проблеми. У наш час спостерігається активізація звернень до психологів з метою отримання кваліфікованої допомоги. Усе більше людей разом з консультантом-психологом обговорюють питання міжособистісної взаємодії, ефективності у професійній діяльності, сімейних конфліктів тощо.

Ми можемо констатувати, що серед факторів звернень до того чи іншого спеціаліста - його професійні знання й уміння, досвід практичної діяльності, відгуки відвідувачів та враження від спілкування при знайомстві. Люди, які потребують психологічної допомоги, звертають увагу не лише на досвід та професійну підготовку спеціаліста, а й на його привабливість, відкритість, здатність до комунікації. Саме тому все частіше дослідники підкреслюють необхідність і важливість урахування соціально- психологічних детермінант взаємодії в системі стосунків психолог - клієнт, зокрема, розвитку міжособистісної атракції. Останню ми представляємо як структурну складову міжособистісного сприймання, що характеризує односторонню чи взаємну привабливість учасників комунікативного процесу.

3 огляду на практику консультування та презентовані в науковій літературі дослідження можна виділити серед актуальних аспектів міжособистісної атракції психолога і клієнта такі: позитивне емоційне ставлення, схожість поглядів на сучасне суспільство, а також психологічні настанови, готовність до змін, індивідуально-типологічні характеристики. 
Метою cmammi $є$ теоретичний огляд наукових підходів до вивчення психологічних факторів атракції та емпіричне визначення основних рис, якими повинен володіти атрактивний психолог.

Аналіз останніх досліджень $\boldsymbol{i}$ публікацій. Проблема атракції активно досліджувалася в зарубіжній соціальній психології, де склався ряд авторських концепцій, які пояснюють виникнення атракції, серед яких: теорія взаємодії результатів Д. Тібо, Г. Келлі, теорія соціального обміну Д. Хоманса, теорія збалансованих структур та атрибуції Ф. Хайдера, теорія когнітивного дисонансу Л. Фестінгера, теорія комунікативних актів Т. Ньюкома, теорія конгруентності Ч. Осгуда і П. Танненбаума. Серед вітчизняних дослідників та психологів близького зарубіжжя проблему атракції вивчали О. Бодальов, Л. Гозман, Г. Андреєва, В. Казміренко, Н. Казарінова, В. Лабунська, В. Фомічева та ін. На основі цих теорій встановлено, що дефініції досліджуваного поняття представлено в діапазоні когнітивних процесів (сприймання, уява) та емоційних оцінок (симпатія, прийняття, емпатійне ставлення).

У широкому значенні під атракцією (від англ. attraction привабливість, притягання) розуміють позитивні почуття, які виникають в однієї людини стосовно іншої. Атракція виникає внаслідок оцінки суб'єктом свого емоційного ставлення, яке породжує гаму почуттів у діапазоні від неусвідомленого потягу до симпатії, любові та проявляється у вигляді особливої соціальної настанови щодо суб'єкта взаємодії. Зовнішні дані, соціально-демографічні характеристики, поведінкові паттерни людини традиційно вважали головною причиною симпатії та антипатії до неї з боку інших людей [Гозман, 1998].

У зарубіжній психології «міжособистісною атракцією», зокрема, позначають когнітивний компонент емоційного ставлення до іншої людини, соціальну настанову, емоційний компонент міжособистісного сприймання [Изард, 2008]. У вітчизняному науковому просторі вченими як основу дослідження міжособистісної атракції виокремлено мотиваційну складову, емоційне ставлення до партнера взаємодії, систему цінностей, закономірності соціальної перцепції тощо [Бодалев, 1995; Додонов, 1987]. Наш аналіз показує, що погляди та емпіричні дані дослідників були оформлені у вигляді цілісних теорій та окремих концептуальних положень.

Виклад основного матеріалу. Починаючи 3 перших кроків комунікації, вже під час первинного контакту між людьми виникають специфічні емоційні взаємини, які визначають привабливість одного індивіда для іншого. Виникнення при сприйманні індивіда індивідом взаємної привабливості, розуміння та прийняття один одного у взаємодії, коли не тільки узгоджуються дії, а й встановлюються позитивні взаємини, у психологічній науці означено як міжособистісна атракція.

Активне дослідження проблем міжособистісної взаємодії в зарубіжній і вітчизняній психології сприяло виникненню ряду авторських концепцій формування атракції та виокремленню різних факторів даного 


\section{Psychology}

явища. Так, А. Лотт і Б. Лотт до факторів виникнення міжособистісної привабливості відносять частоту виникнення і кооперативний характер взаємодії, об'єктивну взаємозалежність учасників спільної діяльності, при якій досягнення цілей здійснюється шляхом об'єднання спільних зусиль, розподілу функцій, ролей та обов'язків [Бодалев, 1995].

Згідно $з$ теорією емоційної готовності до діяльності, Н. Шварц і Дж. Клор особливу увагу звертають на мотиваційну функцію емоцій при виборі стратегії поведінки та формуванні оцінки партнера по спілкуванню. Так, коли людина перебуває в хорошому настрої, емоції ій сигналізують, що дана ситуація не $\epsilon$ проблемною і тому немає потреби в її детальному аналізі, що сприяє продовженню взаємодії [Изард, 2008].

Значне місце при виникненні атракції вчені надають психологічним настановам, диференціюючи їх на важливі та другорядні, що дозволяє визначити міру їх впливу на виникнення міжособистісної привабливості. Зокрема, Д. Бірн виявив, що симпатія виникає тоді, коли схожість настанов виявляється за важливими якостями, а відмінність - за другорядними, менш значущими для конкретної людини. Таким чином, кожна людина оцінюе свої якості та переваги інших людей не лише як позитивні та негативні, а й як важливі, значущі та другорядні, менш важливі. Очевидно, що така оцінка має суб’єктивний характер і може змінюватися під впливом пережитого досвіду чи життєвої ситуації.

Не відкидаючи значення внутрішніх факторів виникнення психологічної привабливості, М. Лернер вказує, що в міжособистісній симпатії важливе значення набувають умови, в яких здійснюється або передбачається взаємодія між партнерами. До них належать зовнішні фактори, врахування яких необхідне для вивчення складного механізму виникнення тяжіння і симпатій, привабливості [Додонов, 1987]. Л. Гозман у виникненні міжособистісної привабливості виділяе фактор просторової близькості, частоту контактів, співробітництво, позитивне підкріплення [Гозман, 1998].

Узагальнюючи вітчизняні та зарубіжні дослідження, пропонує цілу систему показників аналізу міжособистісної симпатії і головним, що зближує чи відштовхує людей, він визнає фактор подібності і контрасту. Другим за значущістю фактором, на думку вченого, є ієрархія якостей людини як суб'єкта праці, пізнання, спілкування. Вікові та статеві відмінності виявляються пов'язаними 3 першими двома факторами i фактично $€$ іншою важливою координатою, яка визначає характер міжособистісної привабливості [Кон, 1989].

Особливу увагу звертають на себе роботи М. Обозова, де була здійснена спроба об'єднати ці два підходи у вивченні атракції. Учений вважає, що подібність і контраст мають розглядатися не ізольовано, а у взаємозв'язку одне з одним. Окрім того, важливо знати, на якому рівні індивідуально-особистісних характеристик виявляється схожість/контраст двох людей, які відчувають взаємну привабливість. 
Включаючись у взаємодію, люди шукають згоди, причому на перших етапах контакту такими маркерами є думки про менш значущі для особистості події, факти. 3 поглибленням взаємодії, зі збільшенням тривалості і значущості спільної діяльності та спілкування, роль інтересів і ціннісних орієнтацій посилюється. На основі цього автор концепції приходить до висновку про важливість не стільки схожості периферійних інтересів, скільки ціннісно-орієнтаційна єдність [Обозов, 1990]. Очевидно, йдеться про збереження взаємно привабливих стосунків протягом тривалого періоду, які вибудовуються на основі узгоджених цілей, мотивів, змістових навантажень та довіри.

3 огляду на раніше опубліковані дослідження, В. Куніцина виділяє дві групи факторів при виникненні атракції:

а) зовнішні фактори: емоційний стан партнерів по спілкуванню (якщо людина позитивно налаштована, переживає позитивні емоції, вона $€$ більш доброзичливою стосовно інших); потреба в довірі (бажання подобатися, відчувати себе цінною та значущою); просторова близькість (чим ближче співрозмовники знаходяться один до одного, тим більша ймовірність виникнення симпатіi);

б) внутрішні фактори: зовнішність (фізична привабливість сприяє виникненню атракції); стиль спілкування (велике значення має схожість стилів партнерів по спілкуванню); подібності між партнерами (схожість настанов, інтересів та ін.) [Куницыьна, 2001].

Виходячи $з$ вище зазначеного, можна констатувати факт значних розбіжностей поглядів як на природу, так i на процес становлення міжособистісної атракції. Стосовно професійної діяльності, зокрема, діяльності психологів, то питання міжособистісної привабливості розглядаються опосередковано, як фактор впливу.

3 метою визначення провідних рис, якими має володіти сучасний атрактивний психолог, було проведено пілотне дослідження - анкетування випускників-психологів та професійних психологів зі стажем роботи від 5 років. Результати даного опитування представлено у табл. 1.

Як видно 3 табл. 1, найвищий рейтинг в обох вибірках отримали компетентність та професіоналізм, що $є$ основним критерієм в роботі спеціаліста, зокрема, й атрактивного психолога. Психологи зі стажем практичної роботи психолога-консультанта важливого значення надають таким рисам, як: освіченість, ерудиція, привітність, доброзичливість, компетентність, комунікабельність, асертивність, толерантність, почуття гумору, що перегукується з думкою зарубіжних фахівців з різних галузей прикладної психології. 


\section{Ранжування рис привабливості психолога}

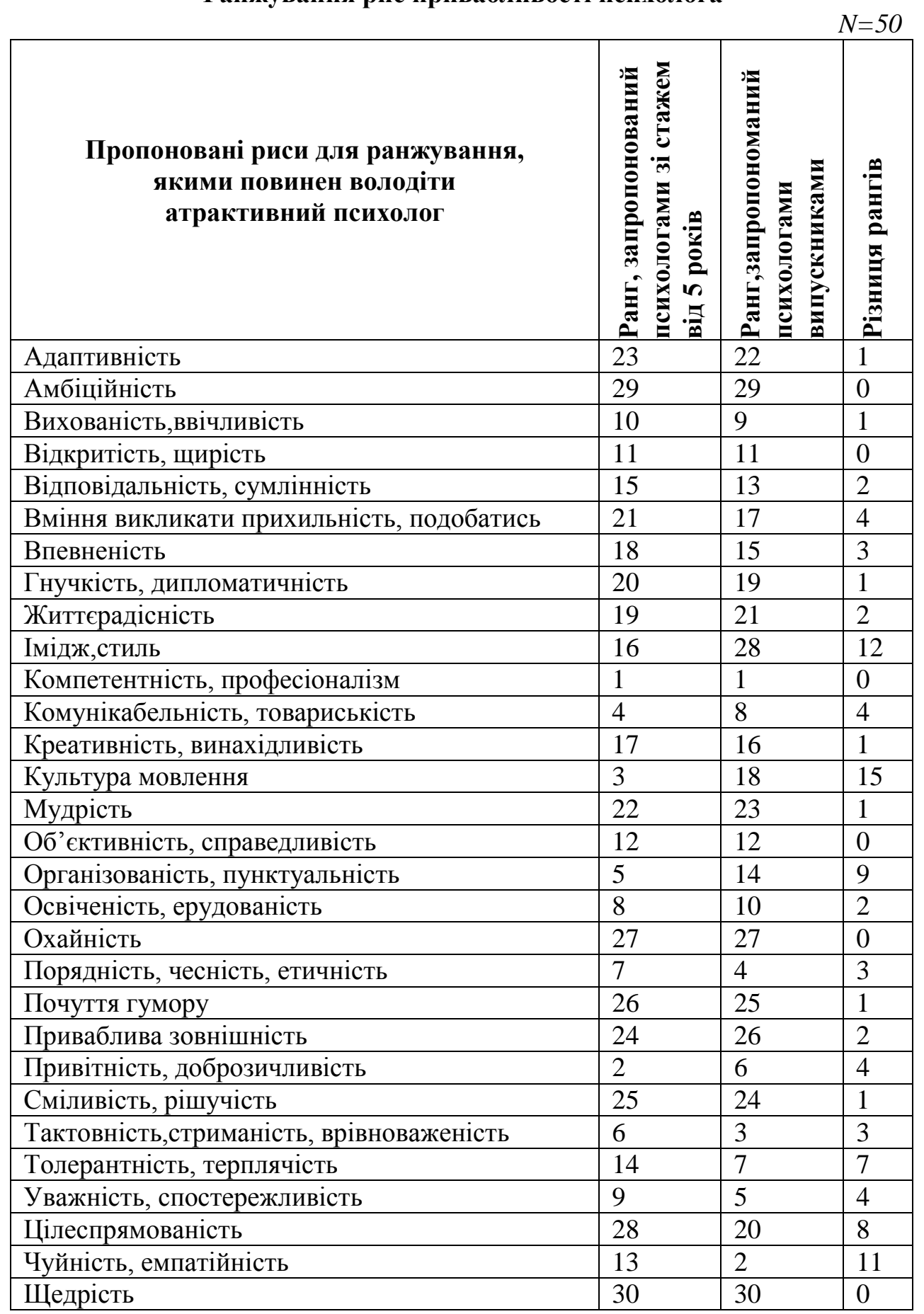


Психологи-випускники в першу чергу виокремлюють такі риси, як: чуйність, емпатійність, тактовність, стриманість, врівноваженість, порядність, чесність, етичність, уважність і спостережливість. Рангові значення у вибірках психологів-випускників та спеціалістів зі стажем найбільш відрізняються за такими рисами, як: імідж, стиль; культура мовлення, організованість, пунктуальність, толерантність, терплячість, цілеспрямованість, чуйність, емпатійність.

У повсякденному житті спершу ми сприймаємо зовнішність людини. У західних соціально-психологічних дослідженнях саме привабливій зовнішності надають ключового значення при виникненні атракції. Цілком очевидно, що вплив зовнішньої привабливості досить значний на етапі формування першого враження. Зовні приваблива людина наділяється соціально бажаними рисами, такими як інтелектуальність, доброта, інтелігентність, товариськість тощо.

Для виникнення атракції стосовно психолога більш важливого значення у звітах професіоналів набувають такі характеристики суб'єкта, як освіченість, ерудиція, енергія, оптимізм. Також важливим $\epsilon$ вміння вести бесіду, привернути до себе увагу, товариськість, бажання підтримувати дружні стосунки з оточуючими, емоційний стан людини. Похмура людина менше цікавить інших, ніж життєрадісна і привітна. Важливе значення у формуванні атракції, на думку досвідчених психологів-практиків, має емпатія як емоційний відгук на переживання іншої людини.

Важливим фактором атракції, на думку студентів та психологівпрактиків є стиль спілкування, особливості вербальної і невербальної поведінки. Яким чином психолог поводиться в розмові, як слухає, реагує все це приваблює або відштовхує співрозмовників. Зарозумілість, амбітність, нетактовність відлякує людей, перешкоджає ефективній роботі.

На думку викладачів психології, фахівець повинен стежити за своїм мовленням, яке «демонструє інтелект людини», а, отже, працює на ії імідж i сприяє виникненню атракції. Правильний літературний стиль мовлення викликає повагу і довіру у співрозмовника. Голос також є невід'ємною складовою іміджу, він може посилити або, навпаки, послабити вплив на співрозмовника. Тихий нечіткий голос демонструє невпевненість або байдужість, що може спричинити недовіру. Занадто гучний голос може свідчити про авторитарний стиль в роботі, що також позначиться негативно. Мелодійність, плавність, теплота i чарівність голосу приваблюють і подобаються співрозмовникові.

У ситуації тривалої взаємодії важливим фактором атракції виступає підкріплення. У реальному спілкуванні підкріплення, які надходять від іншої людини, виступають найчастіше у вигляді демонстрації на вербальному або невербальному рівні свого позитивного ставлення. Важливе значення має посмішка, вплив якої полягає в тому, що співрозмовник отримує сигнал: «Я ваш друг», тому що більшість людей по-доброму посміхаються своїм друзям. Друг, відповідно до словника 


\section{Psychology}

української мови, - це «прихильник, захисник», а однією з базових потреб людини є потреба в безпеці, захищеності. Коли потреба задовольняється, це супроводжується позитивними емоціями. Людина завжди тяжіє до того, хто викликає саме таку реакцію. Очевидно, що у процесі спілкування атрактивний психолог має мати на обличчі добрий та зацікавлений вираз, легку посмішку.

Ім'я також слугує засобом формування атракції в міжособистісній взаємодії, це символ особистості, іiі візитівка. Відомо, що людині приємно чути своє ім'я. Коли ми хочемо переконати когось, то мимоволі і досить часто згадуємо його ім'я. Шанобливо вимовляти ім'я - важливий крок у досягненні атракції. Те, що психолог запам'ятав ім'я відвідувача (особливо після давньої та нетривалої розмови) - це своєрідний комплімент. Коли до людини звертаються, не називаючи імені - це «знеособлене» звернення. У цьому випадку людина цікавить нас не як особистість, а як об'єкт службових функцій. Отримуючи підтвердження своїй «впізнаваності», значущості, у людини виникає задоволення, яке супроводжується позитивними емоціями та мотивує до комунікації.

Пози та жести також відіграють значну роль у формуванні атракції. Нахилений до нас співрозмовник сприймається як уважний слухач, коли ж співрозмовник відкидається назад, а тим більше сидить, розслабившись, ми відчуваємо певну незручність, інколи тривогу, що перешкоджає формуванню атракції.

Встановлено, коли співрозмовники симпатизують один одному або прийшли до спільної думки, то вони мимоволі повторюють пози і жести один одного. У даному випадку можливі два варіанти виникнення міжособистісної атракції: та, що пов'язана з підкріпленням, яке виникає в результаті усвідомлення позитивного ставлення до нас, або, відчуваючи атракцію до когось, ми декодуємо та інтерпретуємо дії цієї людини так, щоб зробити висновок про ii позитивне ставлення до нас [Михайлова, 2007]. Наші спостереження, бесіда 3 досліджуваними психологами та майбутніми спеціалістами в галузі психології підтвердили висновки вчених.

Атракція формується на основі того, що кожен сигнал, який надходить людині від органів чуттів, а також емоційне ставлення зберігаються в пам'яті певний час. Слід може бути негативним, позитивним або нейтральним, при цьому кожен сигнал партнера має для нас певне значення. Саме тому кожен клієнт, часто не усвідомлюючи цього, створює позитивний або негативний образ фахівця, вирішуючи подальшу долю міжособистісної взаємодії.

Висновки та перспективи подальщих розвідок у даному напрямі. Виникнення атракції у спілкуванні людей залежить від багатьох факторів, які можуть бути як зовнішніми стосовно суб'єкта та об'єкта спілкування, так і внутрішніми. Зовнішні фактори атракції - це ті, які не мають прямого зв'язку з процесом спілкування між людьми. Сюди ми відносимо зовнішню 
привабливість, ситуацію спілкування, оточення. До внутрішніх факторів формування атракції відносять особистісні якості суб'єкта і об'єкта, стиль їхньої взаємодії та емоційного ставлення до співрозмовника.

Зовнішній вигляд і поведінка людини формують перше враження, вони можуть виступати носіями певної інформації та відіграють роль сигналів. Ці фактори атракції формуються в момент безпосереднього спілкування, можуть відштовхнути або привабити співрозмовника. Тривалі стосунки формуються на основі певних рис особистостей, їхніх смислових стратегій, цінностей, психологічних настанов і життєвих сценаріїв. Саме ці аспекти стануть предметом наших наступних наукових розвідок.

\section{ЛІТЕРАТУРА}

Бодалев, 1995 - Бодалев А. А. Личность и общение : избранные психологические труды. Москва : Междунар. пед. академия, 1995. 328 с.

Гозман, 1998 - Гозман Л. Я., Алжихина Н. Н. Психология симпатии. Москва : Знание, 1998. 96 с. Додонов, 1987 - Додонов Б. И. В мире эмоций. Киев : Политиздат Украины, 1987. 140 с.

Изард, 1980 - Изард К. Эмоции Человека / под ред. Л. Я. Гозман, М. С. Егоровой. Москва : Издательство МГУ, 1980. 440 с.

Изард, 2008 - Изард К. Психология эмоций. Санкт-Петербург : Питер, 2008. 464 с.

Кон, 1989 - Кон И. С. Дружба : этико-психологический очерк. Москва : Политиздат, 1989. 35 с.

Куницына, 2001 - Куницына В. Н., Казаринова Н. В., Погольша В. М. Межличностное общение : учебник для вузов. Санкт-Петербург : Питер, 2001. 544 с.

Михайлова, 2007 - Михайлова Е. В. Самопрезентация : теории, исследования, тренинг. СанктПетербург : Речь, 2007. 224 с.

Обозов, 1990 - Обозов Н. Н. Психология межличностных отношений. Киев : Издательство «Лыбидь» при Киевском университете, 1990. 192 с.

\section{REFERENCES}

Bodalev, 1995 - Bodalev A. A. Lichnost i obschenie : izbrannyie psihologicheskie trudyi. Moskva: Mezhdunar. ped. akademiya, 1995. 328 s.

Gozman, 1998 - Gozman L. Ya., Alzhihina N. N. Psihologiya simpatii. Moskva : Znanie, 1998. 96 s.

Dodonov, 1987 - Dodonov B. I. V mire emotsiy. Kiev : Politizdat Ukrainyi, 1987. $140 \mathrm{~s}$.

Izard, 1980 - Izard K. Emotsii Cheloveka / pod red. L. Ya. Gozman, M. S. Egorovoy. Moskva : Izdatelstvo MGU, 1980. $440 \mathrm{~s}$.

Izard, 2008 - Izard K. Psihologiya emotsiy. Sankt-Peterburg : Piter, 2008. 464 s.

Kon, 1989 - Kon I. S. Druzhba : etiko-psihologicheskiy ocherk. Moskva : Politizdat, 1989. 35 s.

Kunitsyina, 2001 - Kunitsyina V. N., Kazarinova N. V., Pogolsha V. M. Mezhlichnostnoe obschenie: uchebnik dlya vuzov. Sankt-Peterburg : Piter, 2001. $544 \mathrm{~s}$.

Mihaylova, 2007 - Mihaylova E. V. Samoprezentatsiya: teorii, issledovaniya, trening. SanktPeterburg : Rech, 2007. $224 \mathrm{~s}$.

Obozov, 1990 - Obozov N. N. Psihologiya mezhlichnostnyih otnosheniy. Kiev : Izdatelstvo «Lyibid» pri Kievskom universitete, 1990. $192 \mathrm{~s}$. 